\title{
Gas chromatography and photoacoustic spectroscopy for the assessment of soil greenhouse gases emissions
}

\author{
Cromatografia gasosa e espectroscopia fotoacústica para avaliação das emissões de gases de efeito \\ estufa do solo
}

\author{
Rodrigo da Silveira Nicoloso ${ }^{\text {I* }}$ Cimélio Bayer ${ }^{\text {II }}$ Genuir Luis Denega ${ }^{\text {III }}$ \\ Paulo Armando Victória de Oliveira ${ }^{\mathrm{I}}$ Martha Mayumi Higarashi ${ }^{\mathrm{I}}$ Juliano Corulli Corrêa \\ Letícia dos Santos Lopes ${ }^{\mathrm{I}}$
}

\begin{abstract}
Assessments of soil carbon dioxide $\left(\mathrm{CO}_{2}\right)$, methane $\left(\mathrm{CH}_{4}\right)$, and nitrous oxide $\left(\mathrm{N}_{2} \mathrm{O}\right)$ emissions are critical for determination of the agricultural practices' potential to mitigate global warming. This study evaluated the photoacoustic spectroscopy (PAS) for the assessment of soil greenhouse gases $(G H G)$ fluxes in comparison to the standard gas chromatography $(G C)$ method. Two long-term experiments with different tillage and cropping systems over a Paleudult were evaluated using static chambers. PAS measurements of $\mathrm{CO}_{2}$ and $\mathrm{N}_{2} \mathrm{O}$ concentrations showed good relationship and linearity $\left(R^{2}=0.98\right.$ and 0.94 , respectively) with $\mathrm{GC}$ results. However, $\mathrm{CH}_{4}$ measurements were significantly affected by air sample moisture which interfered on $\mathrm{CH}_{4}$ detection by PAS. Overestimation of $\mathrm{CO}_{2}$ and $\mathrm{N}_{2} \mathrm{O}$ concentrations in air samples determined by PAS ( 14.6 and $18.7 \%$, respectively) were also related to sampling moisture. $\mathrm{CO}_{2}$ and $\mathrm{N}_{2} \mathrm{O}$ fluxes showed good agreement between methods $\left(R^{2}=0.96\right.$ and 0.95 , respectively), though PAS overestimated fluxes by 18.6 and $13.6 \%$ in relation to GC results, respectively. PAS showed good sensitivity and was able to detect $\mathrm{CO}_{2}$ and $\mathrm{N}_{2} \mathrm{O}$ fluxes as low as $332 \mathrm{mg} \mathrm{CO}_{2} \mathrm{~m}^{-2} h^{-1}$ and $21 \mu \mathrm{g} \mathrm{N} \mathrm{N} \mathrm{m}^{-2} h^{-1}$. PAS analyzer should be detailed calibrated to reduce humidity interference on $\mathrm{CO}_{2}, \mathrm{CH}_{4}$ and $\mathrm{N}_{2} \mathrm{O}$ concentrations measurements avoiding overestimation or erroneous determination of soil GHG fluxes.
\end{abstract}

Key words: no-tillage, conventional tillage, cover crops, INNOVA 1412.

\section{RESUMO}

As avaliações das emissões de dióxido de carbono $\left(\mathrm{CO}_{2}\right)$, metano $\left(\mathrm{CH}_{4}\right)$ e óxido nitroso $\left(\mathrm{N}_{2} \mathrm{O}\right)$ do solo são fundamentais para a determinação do potencial de práticas agrícolas em mitigar o aquecimento global. Este estudo avaliou

\begin{abstract}
a espectroscopia fotoacústica (EFA) para a determinação dos fluxos de gases de efeito estufa (GEE) do solo em comparação com o método padrão de cromatografia gasosa (CG). Dois experimentos de longa duração com diferentes sistemas de preparo do solo e rotação de culturas sobre um Argissolo foram avaliados usando câmaras estáticas. As medidas das concentrações de $\mathrm{CO}_{2}$ e $\mathrm{N}_{2} \mathrm{O}$ realizadas por EFA mostraram boa correlação e linearidade $\left(R^{2}=0,98\right.$ e 0,94; respectivamente) com os resultados de CG. Entretanto, as medidas de $\mathrm{CH}_{4}$ foram significativamente afetadas pela umidade da amostra de ar que interferiu na detecção do $\mathrm{CH}_{4}$ por EFA. A superestimativa das concentrações de $\mathrm{CO}_{2}$ e $\mathrm{N}_{2} \mathrm{O}$ nas amostras analisadas por EFA (14,6 e 18,7\%; respectivamente) também foram relacionadas com o conteúdo de umidade da amostra. Os fluxos de $\mathrm{CO}_{2}$ e $\mathrm{N}_{2} \mathrm{O}$ mostraram boa correlação entre os métodos $\left(R^{2}=0,96\right.$ e 0,95; respectivamente), apesar da superestimativa dos fluxos determinados por EFA ter sido de 18,6 e 13,6\% em relação aos resultados obtidos por $C G$, respectivamente. A EFA mostrou boa sensibilidade e foi capaz de detectar fluxos de $\mathrm{CO}_{2}$ e $\mathrm{N}_{2} \mathrm{O}$ tão baixos quanto $332 \mathrm{mg} \mathrm{CO}_{2} \mathrm{~m}^{-2} \mathrm{~h}^{-1}$ and $21 \mu \mathrm{g}$ $\mathrm{N}_{2} \mathrm{O} \mathrm{m}^{-2} h^{-1}$. A calibração detalhada do analisador fotoacústico para reduzir a interferência da umidade das amostras nas medidas das concentrações de $\mathrm{CO}_{2}, \mathrm{CH}_{4}$ e $\mathrm{N}_{2} \mathrm{O}$ deve ser realizada a fim de evitar superestimativa ou erro na determinação dos fluxos de GEE do solo.
\end{abstract}

Palavras-chave: plantio direto, preparo convencional, plantas de cobertura, INNOVA 1412.

\section{INTRODUCTION}

Agriculture is responsible for 5, 47, and 84\% of the global carbon dioxide $\left(\mathrm{CO}_{2}\right)$, methane $\left(\mathrm{CH}_{4}\right)$, and

'Embrapa Suínos e Aves, 89700-000, Concórdia, SC, Brasil. E-mail: rodrigo.nicoloso@embrapa.br. *Autor para correspondência. "Departamento de Solos, Universidade Federal do Rio Grande do Sul (UFRGS), Porto Alegre, RS, Brasil.

IIIPrograma de Pós-graduação em Ciência do Solo, UFRGS, Porto Alegre, RS, Brasil. 
nitrous oxide $\left(\mathrm{N}_{2} \mathrm{O}\right)$ emissions to the atmosphere, respectively (RICE, 2006). Recent research initiatives are being conducted aiming to identify agricultural practices able to mitigate GHG emissions. However, some concern persists about the methodologies available for evaluation of $\mathrm{CO}_{2}, \mathrm{CH}_{4}$ and $\mathrm{N}_{2} \mathrm{O}$ fluxes in the soil-atmosphere interface since intensive labor is required for sample collection and laboratory analysis.

Soil-atmosphere $\mathrm{CO}_{2}$ fluxes are generally assessed through the balance of soil organic carbon stocks in long-term experiments (BAYER et al., 2006). However, the evaluation of soil $\mathrm{CO}_{2}$ efflux is an important tool to identify short-term $\mathrm{CO}_{2}$ fluxes induced by soil tillage and sowing operations or by the incorporation of crop residues into the soil (CHAVEZ et al., 2009), decomposition of soil organic matter and crop residues (PÊS et al., 2011), and the effect of soil and crop management strategies on the improvement of soil organic carbon stabilization (CAMPOS et al., 2011).

The $\mathrm{CH}_{4}$ fluxes are more relevant in flooded soils where the incorporation of crop residues increases methanogenesis (ZSCHORNACK et al., 2011), but short-term $\mathrm{CH}_{4}$ emissions could also be verified in aerated soils following manure or nitrogen fertilizer amendments (SHERLOCK et al., 2002; ZANATTA et al., 2010). $\mathrm{N}_{2} \mathrm{O}$ emissions are critical on aerated soils under nitrogen fertilization or inclusion of legumes on the cropping systems (ESCOBAR et al., 2010; ZANATTA et al., 2010).

Most of studies assessing $\mathrm{CH}_{4}$ and $\mathrm{N}_{2} \mathrm{O}$ fluxes in soil-atmosphere interface are performed by using static chambers for gas sampling and further gas chromatography (GC) analysis (ESCOBAR et al., 2010; GOMES et al., 2009; ZANATTA et al., 2010). Fluxes are then calculated by the linear increase of GHG concentration in the chamber air in a given period (usually $<60 \mathrm{~min}$ ). Although accurate, conjunct analysis of $\mathrm{CO}_{2}, \mathrm{CH}_{4}$ and $\mathrm{N}_{2} \mathrm{O}$ by GC imposes operational limitations on the number of gas samples that could be feasible collected and analyzed. Therefore, it is very important to have some alternative method for accurate GHG evaluation allowing improvement of sampling frequency and number of experiments, treatments and replicates under analysis.

Few techniques are available for the simultaneous assessment of the three GHG with significant success. Among them, the photoacoustic spectroscopy (PAS) method has been proposed for the conjunct assessment of $\mathrm{CO}_{2}, \mathrm{CH}_{4}$ and $\mathrm{N}_{2} \mathrm{O}$ fluxes in substitution to GC. However, this technique is still unprecedented in studies assessing soil GHG emissions in Brazil. Among the main advantages of this method are its sensitivity and linearity for $\mathrm{CO}_{2}$,
$\mathrm{CH}_{4}$ and $\mathrm{N}_{2} \mathrm{O}$ concentrations, real-time gas sampling and measurement (avoiding sampling storage and laboratory analysis), and portability (YAMULKI \& JARVIS, 1999). Studies assessing soil GHG emissions through PAS have been carried out with success (VELTHOF et al., 2003; LOVANH et al., 2010), although some concern persists when very low GHG fluxes should be measured. PAS analysis could be able to detect $\mathrm{N}_{2} \mathrm{O}$ fluxes of $65.6 \mu \mathrm{g} \mathrm{N} \mathrm{N}_{2} \mathrm{O} \mathrm{m}^{-2} \mathrm{~h}^{-1}$ (YAMULKI \& JARVIS, 1999). However, NT soils without $N$ input could present $\mathrm{N}_{2} \mathrm{O}$ fluxes as low as $13.5 \mu \mathrm{g} \mathrm{N}_{2} \mathrm{O} \mathrm{m}^{-2} \mathrm{~h}^{-1}$ (GOMES et al., 2009). Thus, the objective of this study was to evaluate the efficiency and sensitivity of a PAS trace-gas analyzer on the assessment of soil GHG emissions in static chambers taking the standard GC method as reference.

\section{MATERIAL AND METHODS}

This study was carried out in two long-term experiments (3006' $\mathrm{S}$; $51^{\circ} 40^{\prime} \mathrm{W}$; $46 \mathrm{~m}$ altitude) in Eldorado do Sul, state of Rio Grande do Sul, Brazil. The climate is subtropical humid Cfa according to the Köppen classification, with a mean annual temperature and rainfall of $19.4^{\circ} \mathrm{C}$ and $1440 \mathrm{~mm}$, respectively. The local soil is classified as a Paleudult (U.S. Soil Taxonomy) or a sandy clay loam Acrisol (FAO).

The first long-term experiment was established in 1983 with different cropping systems under no-till (NT). Three treatments (with two replications) were selected with increasing $\mathrm{C}$ and $\mathrm{N}$ inputs to the soil by crop rotations (winter/summer species): (a) fallow/maize (Zea mays L.), (b) black oat (Avena strigosa Schreb.)+vetch (Vigna sativa L.)/maize, and (c) black oat+vetch/maize+cowpea (Vigna unguiculata (L.) Walp.) without mineral $\mathrm{N}$ fertilization. Further details of the experiment and crop conduction are available in VIEIRA et al. (2009). The second longterm experiment was initiated in 1985 with different soil tillage (NT; and CT - conventional tillage) and cropping systems. For this study, four treatments (with three replications) were selected with increasing soil disturbance by tillage and $\mathrm{C}$ and $\mathrm{N}$ inputs by cropping systems (winter/summer species): (1) CT with black oat/ maize; (2) CT with vetch/maize; (3) NT with black oat/ maize; and (4) NT with vetch/maize; without mineral N fertilization. Further description of the experiment and crop conductions was detailed by ZANATTA et al. (2007). Treatments from both experiments were selected in order to provide a wide range of GHG concentrations and fluxes for better methods comparison.

Air samples were collected in static chambers measuring $40 \times 80 \times 40 \mathrm{~cm}(\mathrm{LxWxH})$ and 
mounted over a base with $9 \mathrm{~cm}$ of height. The headspace volume of the chambers averaged $70.4 \mathrm{~L}$. The chambers were equipped with three internal fans to homogenize the internal atmosphere before sampling, a probe thermometer for monitoring the air temperature inside chamber and a rubber septum from where air samples were taken through a plastic tube closed by a threeway "luer-lock" valve.

Air sampling was performed in Sep. 22, 2011 (experiment 2) and Sep. 23, 2011 (experiment 1). Chambers were closed and sealed with water to avoid air exchanges between atmospheres inside and outside the chambers. The samples at time zero were collected outside the chamber, while the samples from the atmosphere inside chamber were collected after 15, 30, and $45 \mathrm{~min}$. The samples were collected with $20 \mathrm{~mL}$ polypropylene syringes which were stored in a cooler until GC analysis. Immediately after that, the samples for PAS analysis were taken by the trace-gas analyzer INNOVA 1412 (Lumasense Technologies, Denmark). The analyzer automatically pumped $100 \mathrm{~mL}$ of air from inside the chambers (or outside chamber at time zero) and performed PAS analysis.

Air samples were analyzed in a gas chromatograph (Shimadzu GC 2014A "Greenhouse") equipped with three packed columns at $70^{\circ} \mathrm{C}, \mathrm{N}_{2}$ as carrier gas at a flow of $26 \mathrm{~mL} \mathrm{~min}^{-1}$, an injector with $1 \mathrm{~mL}$ sample loop for direct injection at $250^{\circ} \mathrm{C}$, an electron capture detector (ECD) at $325^{\circ} \mathrm{C}$ for $\mathrm{N}_{2} \mathrm{O}$ detection and flame ionization detector (FID) at $250^{\circ} \mathrm{C}$ for $\mathrm{CH}_{4}$. The equipment was equipped with a methanator which catalytically reduced $\mathrm{CO}_{2}$ to $\mathrm{CH}_{4}$ for analysis of the $\mathrm{CO}_{2}$ gas with the FID detector.

The $\mathrm{CO}_{2}, \mathrm{CH}_{4}$ and $\mathrm{N}_{2} \mathrm{O}$ fluxes were calculated based on the following equation:

$$
f=\frac{\Delta Q}{\Delta t} \frac{P V}{R T} \frac{1}{A}
$$

Where $f$ is the carbon dioxide, methane, and nitrous oxide flux ( $\mathrm{mg} \mathrm{CO}_{2} \mathrm{~m}^{-2} \mathrm{~h}^{-1}$ or $\mu \mathrm{g} \mathrm{N}_{2} \mathrm{O}$ or $\mathrm{CH}_{4} \mathrm{~m}^{-2}$ $\left.\mathrm{h}^{-1}\right), Q$ is the mass of the gas ( $\mathrm{mg} \mathrm{CO}$ or $\mu \mathrm{g} \mathrm{N} \mathrm{O}_{2}$ or $\mathrm{CH}_{4}$ ) inside chamber at a given sampling time $(t), P$ is the atmospheric pressure (atm) in the inner chamber assumed as 1atm, $V$ is the chamber volume (L), $R$ is the constant for ideal gases $\left(0,08205 \mathrm{~atm} \mathrm{~L} \mathrm{~mol}^{-1} \mathrm{~K}^{-1}\right), T$ is the temperature within the chamber at sampling time $(\mathrm{K})$ and $A$ is the basal area of the chamber $\left(\mathrm{m}^{2}\right)$. GHG fluxes were calculated by the angular coefficient of the linear regression adjusted for changes in gas concentrations over time inside chambers.

The INNOVA 1412 trace-gas analyzer pumped and confined the air sample in a sealed compartment where intermittent infrared radiation was applied at the specific wavelength absorbed by the gas of interest to be analyzed. The intermittent radiation promotes pulses of temperature and pressure proportional to the gas concentration in the sample which are registered by two microphones. Detailed description of the method is provided by YAMULKI \& JARVIS (1999). The INNOVA 1412 trace-gas analyzer used in this study was equipped with UA0982 (center wavelength: $14.1 \mu \mathrm{m}), \mathrm{UA} 0985$ $(4.5 \mu \mathrm{m}), \mathrm{UA} 0969(8 \mu \mathrm{m})$, and SB0527 $(5.1 \mu \mathrm{m})$ filters for the analysis of $\mathrm{CO}_{2}, \mathrm{CH}_{4}, \mathrm{~N}_{2} \mathrm{O}$, and water vapor concentrations in the air samples, respectively (LUMASENSE TECHNOLOGIES, 2009). The detection limits for those gases are 1.50, 0.40, 0.03, and 50ppm, respectively, for the analyzer equipped with those filters (at $20^{\circ} \mathrm{C}$ and $1 \mathrm{~atm}$ ) and with a sample integration time of $5 \mathrm{~s}$ for each gas. The equipment was factory calibrated for the above mentioned gases and also for humidity and cross interference among gases. The sample volume $(100 \mathrm{~mL})$ was set to ensure the complete flushing of the internal measurement system of the analyzer $(60 \mathrm{~mL})$, avoiding contamination between samples. The GHG fluxes were calculated by the same procedure described for samples analyzed by GC.

The comparison of GC and PAS methods for determination of GHG concentrations and fluxes was performed by regressions analysis and the significance $(\mathrm{p}<0.05)$ of the coefficient of determination $\left(\mathrm{R}^{2}\right)$ of the adjusted linear equations (SAS INSTITUTE, 2009).

\section{RESULTS AND DISCUSSION}

The results of $\mathrm{CO}_{2}, \mathrm{CH}_{4}$ and $\mathrm{N}_{2} \mathrm{O}$ concentrations in air samples collected in both experiments are presented in the figure 1. For $\mathrm{CO}_{2}$ and $\mathrm{N}_{2} \mathrm{O}$ gases, data collected through PAS showed good relationship with GC results $\left(\mathrm{R}^{2}=0.98\right.$ and 0.94 , respectively, $p<0.001$ ). However, PAS overestimated both gases concentrations compared to $\mathrm{GC}$ ( $14.6 \%$ for $\mathrm{CO}_{2}$ and $18.7 \%$ for $\mathrm{N}_{2} \mathrm{O}$ ). $\mathrm{CH}_{4}$ concentrations determined by PAS showed no correlation with GC results, although previous laboratory studies founded good linearity when comparing both methods (YAMULKI \& JARVIS, 1999).

These results could be associated with humidity interference due to the proximity of absorbed wavelength by water vapor $(5.1 \mu \mathrm{m})$ and the wavelength absorbed by the other GHG gases, especially methane $(4.5 \mu \mathrm{m})$. Increase of air moisture promotes a linear increase of $\mathrm{CO}_{2}, \mathrm{CH}_{4}$, and $\mathrm{N}_{2} \mathrm{O}$ signal detection by PAS when the analyzer is not accordingly calibrated or configured to compensate this interference (YAMULKI \& JARVIS, 1999). This information was confirmed in a 

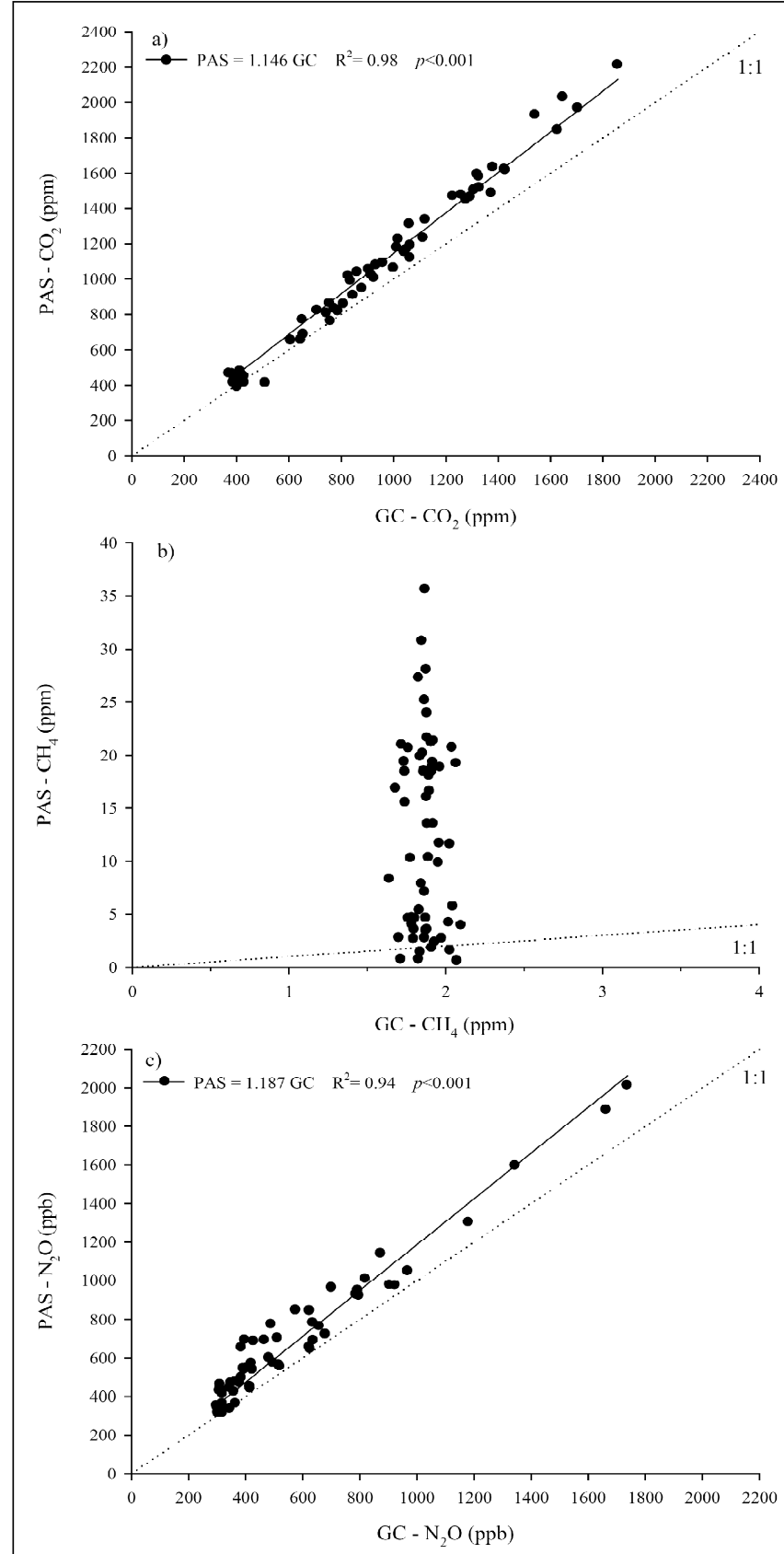

Figure 1 - Relationship between $\mathrm{CO}_{2}$ (a), $\mathrm{CH}_{4}$ (b), and $\mathrm{N}_{2} \mathrm{O}$ (c) absolute concentrations determined by gas chromatography (GC) and photoacoustic spectroscopy (PAS).

laboratory test with the equipment used in this study (data not showed). The trace-gas analyzer used in this study was factory calibrated for humidity interference for water vapor concentration up to $20.60 \mathrm{mg} \mathrm{g}^{-1}$ in the atmosphere. However, the air samples analyzed in this study showed water vapor concentrations ranging from 13.54 to $32.01 \mathrm{mg} \mathrm{g}^{-1}$. Although the trace-gas analyzer was set to compensate humidity interference, the outrange water vapor concentrations in this study could have promoted overestimation of $\mathrm{CO}_{2}$ and $\mathrm{N}_{2} \mathrm{O}$ 
concentrations determined by PAS in relation to GC results, and the lack of relationship between $\mathrm{CH}_{4}$ results from PAS and GC.

An analysis of air moisture interference on $\mathrm{CO}_{2}, \mathrm{CH}_{4}$ and $\mathrm{N}_{2} \mathrm{O}$ results from PAS and $\mathrm{GC}$ analysis is presented in figure 2. Air samples collected at time zero (outside chamber) averaged air moisture content of $15.52 \mathrm{mg} \mathrm{g}^{-1}$, while air samples collected inside chambers (after 15, 30, and $45 \mathrm{~min}$ ) averaged $25.20 \mathrm{mg} \mathrm{g}^{-1}$ of water vapor concentration in the atmosphere. The higher water vapor concentration in the closed chambers could be result of water evapotranspiration from soil or evaporated from the chamber's water seal. The analysis of water interference on GHG concentrations was then performed just for the samples collected inside static chambers (15, 30 and $45 \mathrm{~min}$ sampling time), where air moisture

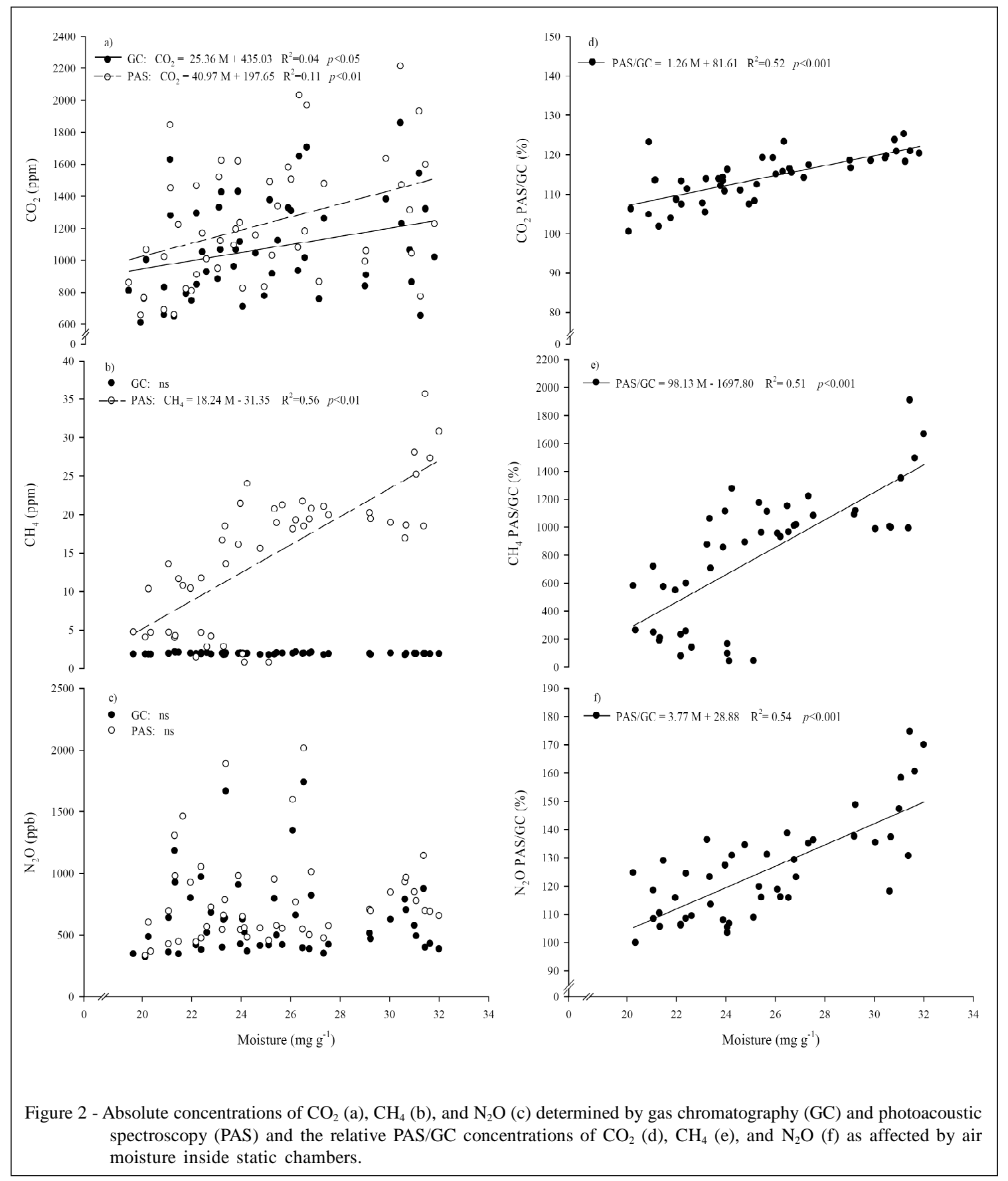

Ciência Rural, v.43, n.2, fev, 2013. 
concentration exceeded the PAS analyzer humidity interference calibration point. Also, variation of GHG and water vapor concentrations in samples collected outside chambers (time zero) was too small to perform such analysis. Weak but significant relationships between air moisture and $\mathrm{CO}_{2}$ concentrations were noticed for both PAS and GC results (Figure 2A). For $\mathrm{CH}_{4}$, PAS results showed strong relationship with water vapor in the air sample, while GC results were not affected by sample moisture (Figure 2B). $\mathrm{PAS}-\mathrm{CH}_{4}$ results indicate that the trace-gas analyzer used in this study was misreading water vapor as $\mathrm{CH}_{4}$, providing the discrepant results showed in the figure 1B. To solve this issue, detailed humidity interference calibration above $20.60 \mathrm{mg}$ $\mathrm{g}^{-1}$ water vapor concentration should be performed for this analyte. On the other hand, $\mathrm{N}_{2} \mathrm{O}$ results from PAS and GC analysis showed no relationship with air moisture (Figure 2C). These results could indicate that air moisture didn't affected $\mathrm{N}_{2} \mathrm{O}$ measurements by PAS or at least the treatments effect were by far superior than humidity interference for this gas.

However, when the relative PAS/GC difference (percentage difference between PAS and GC results) were analyzed for its sensitivity to sample moisture, fitted linear equations showed that PAS- $-\mathrm{CO}_{2}$ and $-\mathrm{N}_{2} \mathrm{O}$ results were also affected by humidity interference (Figure 2D,F). Thus, explaining the cause of PAS overestimation in relation to GC results. The higher slope of the linear equation between relative PAS/GC difference and air moisture fitted for $\mathrm{N}_{2} \mathrm{O}$ also agree with the higher overestimation for $\mathrm{N}_{2} \mathrm{O}$ concentrations verified in figure $1 \mathrm{C}$ in relation to the overestimation verified for $\mathrm{CO}_{2}$ (Figure $2 \mathrm{D}$ and $1 \mathrm{~A}$ ). These results indicate that even for $\mathrm{CO}_{2}$ and $\mathrm{N}_{2} \mathrm{O}$ PAS analysis were being affected by air moisture out of the calibration range and further humidity interference calibration should be performed at higher air moisture levels (at least 32 $\mathrm{mg} \mathrm{g}^{-1}$ ). Relative PAS/GC difference for $\mathrm{CH}_{4}$ (Figure 2E) showed the same pattern observed in the figure $2 \mathrm{~B}$, since air moisture interference was more pronounced for this gas in PAS analysis.

The sensitivity of each GHG analysis method was assessed by the coefficient of determination $\left(\mathrm{R}^{2}\right)$ of the linear equation describing the increase of GHG concentrations inside static chambers with time. Since PAS- $\mathrm{CH}_{4}$ concentrations were erroneous and $\mathrm{GC}-\mathrm{CH}_{4}$ fluxes were too low in both experiments, this comparison was performed only for $\mathrm{CO}_{2}$ and $\mathrm{N}_{2} \mathrm{O}$ (Figure $3 \mathrm{~A}, \mathrm{~B}$ ). Both PAS and $\mathrm{GC}$ showed good sensitivity in all the range of $\mathrm{CO}_{2}$ fluxes observed (PAS: 332 to $871 \mathrm{mg} \mathrm{CO}_{2} \mathrm{~m}^{-2} \mathrm{~h}^{-1}$ ), with $\mathrm{R}^{2}$ always higher than 0.99 (Figure $3 \mathrm{~A}$ ). For $\mathrm{N}_{2} \mathrm{O}, \mathrm{GC}$ showed $\mathrm{R}^{2}$ higher than 0.90 , while PAS showed $\mathrm{R}^{2}$ above 0.81 (Figure 3B) at $\mathrm{N}_{2} \mathrm{O}$ fluxes ranging from 21 to $855 \mu \mathrm{g} \mathrm{N}_{2} \mathrm{O} \mathrm{m}^{-2} \mathrm{~h}^{-1}$. $\mathrm{R}^{2}$ lower than 0.90 , but still highly significant, were noticed for PAS results when $\mathrm{N}_{2} \mathrm{O}$ fluxes were lower than $252 \mu \mathrm{g}$ $\mathrm{N}_{2} \mathrm{O} \mathrm{m}^{-2} \mathrm{~h}^{-1}$. Previous study reported that PAS analysis could be able to detect $\mathrm{N}_{2} \mathrm{O}$ fluxes lower than 11.6ng N$\mathrm{N}_{2} \mathrm{O} \mathrm{m}^{-2} \mathrm{~s}^{-1}$ or $65.6 \mu \mathrm{g} \mathrm{N}_{2} \mathrm{O} \mathrm{m}^{-2} \mathrm{~h}^{-1}$ with acceptable $\mathrm{R}^{2}$ higher than 0.70 (YAMULKI \& JARVIS, 1999). In the present study, PAS were able to detect $\mathrm{N}_{2} \mathrm{O}$ fluxes as low as $3.7 n g ~ N-N_{2} \mathrm{O} \mathrm{m}^{-2} \mathrm{~s}^{-1}$ or $21 \mu \mathrm{g} \mathrm{N}_{2} \mathrm{O} \mathrm{m}^{-2} \mathrm{~h}^{-1}$ with $\mathrm{R}^{2}$ higher than 0.81 . Thus, indicating the high sensitivity of this method for soil GHG emission assessments.

The comparison of $\mathrm{CO}_{2}$ and $\mathrm{N}_{2} \mathrm{O}$ fluxes determined by PAS and $\mathrm{GC}$ are presented in the figure 3C,D. PAS showed good relationship with GC results $\left(\mathrm{R}^{2}=0.96\right.$ and 0.95 , respectively, $\left.p<0.001\right)$. However, PAS overestimated both gases fluxes in relation to $\mathrm{GC}$ ( $18.6 \%$ for $\mathrm{CO}_{2}$ and $13.6 \%$ for $\mathrm{N}_{2} \mathrm{O}$ ). Lower interference of sample moisture on PAS- $\mathrm{N}_{2} \mathrm{O}$ than PAS- $\mathrm{CO}_{2}$ measurements (Figure 2A,C) resulted in lower overestimation of $\mathrm{N}_{2} \mathrm{O}$ than $\mathrm{CO}_{2}$ fluxes determined by PAS. Comparison of $\mathrm{CH}_{4}$ fluxes determined by PAS and GC methods was not performed due to humidity interference errors of PAS- $\mathrm{CH}_{4}$ measurements. PAS showed to be an efficient method for the assessment of soil GHG fluxes in substitution to GC. Further studies considering accurate calibration of the trace-gas analyzer for humidity interference should be carried out to confirm these results.

\section{CONCLUSION}

PAS showed good relationship and linearity with $\mathrm{GC}$ on the assessment of soil $\mathrm{CO}_{2}$ and $\mathrm{N}_{2} \mathrm{O}$ fluxes in static chambers. However, PAS overestimated soil $\mathrm{CO}_{2}$ and $\mathrm{N}_{2} \mathrm{O}$ fluxes by 18.6 and $13.6 \%$ in relation to $\mathrm{GC}$. Detailed calibration of PAS analyzer for humidity interference on $\mathrm{CO}_{2}, \mathrm{CH}_{4}$ and $\mathrm{N}_{2} \mathrm{O}$ measurements should be performed to avoid overestimation and errors on GHG concentrations and fluxes analysis. PAS showed good sensitivity and was able to detect fluxes as low as $332 \mathrm{mg} \mathrm{CO}_{2} \mathrm{~m}^{-2} \mathrm{~h}^{-1}$ and $21 \mu \mathrm{g} \mathrm{N}_{2} \mathrm{O} \mathrm{m}^{-2} \mathrm{~h}^{-1}$.

\section{ACKNOWLEDMENTS}

The authors would like to thank the Conselho Nacional de Desenvolvimento Científico e Tecnológico (CNPq) (process n. 477603/2011-4), Fundação de Amparo à Pesquisa do Estado do Rio Grande do Sul (FAPERGS), and PECUS Research Network from EMBRAPA for their support to this research. 


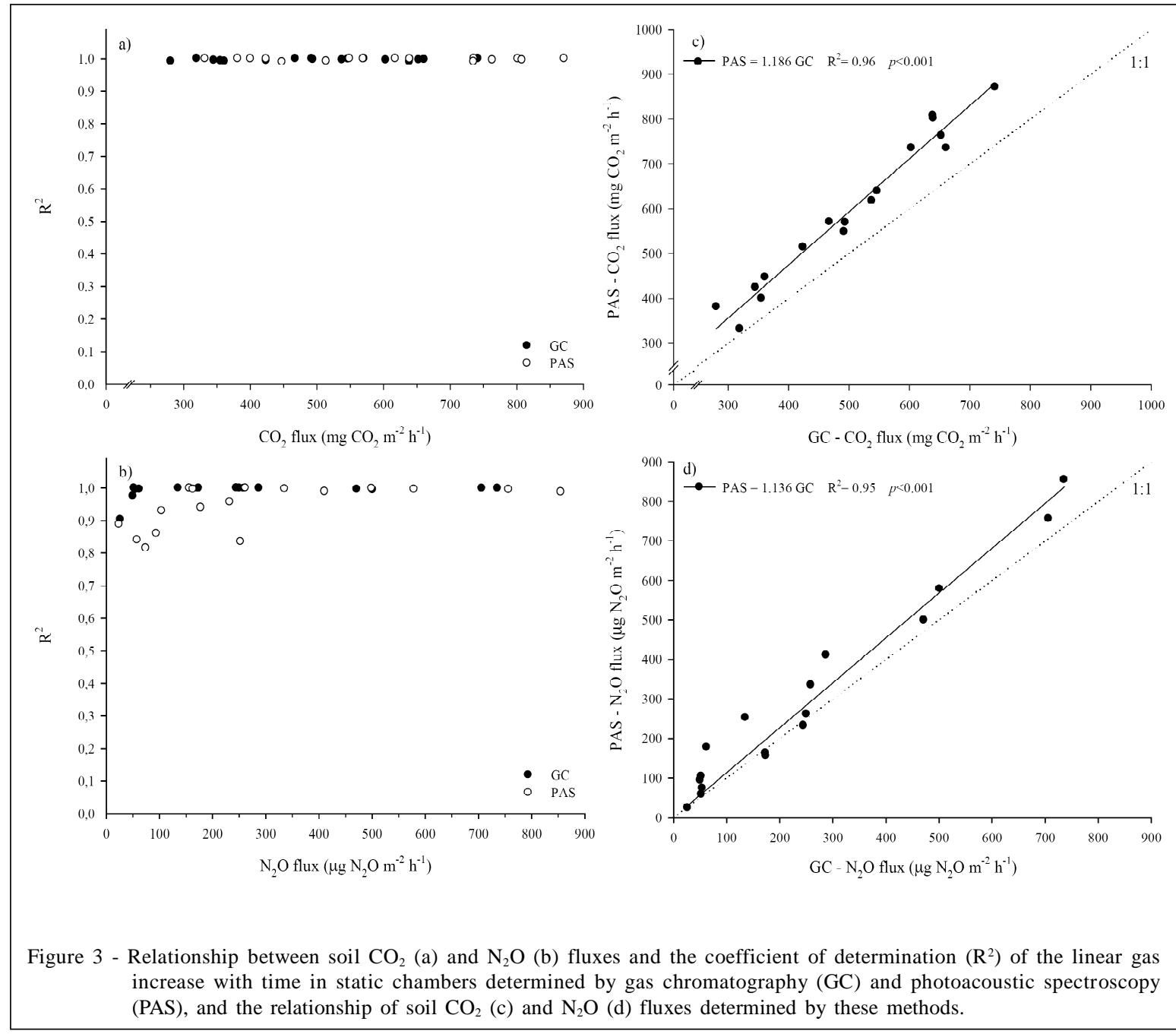

\section{REFERENCES}

BAYER, C. et al. Carbon sequestration in two Brazilian Cerrado soils under no-till. Soil and Tillage Research, v.86, p.237245, 2006. Available from: <http://www.sciencedirect.com/ science/article/pii/S0167198705000723 . Accessed: out. 02, 2012. doi: $10.1016 /$ j.still.2005.02.023.

CAMPOS, B-H.C. et al. Long-term C-CO ${ }_{2}$ emission and carbon crop residue mineralization in an Oxisol under different tillage and crop rotation systems. Revista Brasileira de Ciência do Solo, v.35, p.819-832, 2011. Available from: <http:// www.scielo.br/scielo.php? script=sci_arttext\&pid=S010006832011000300017\&lng=en\&nrm=iso $>$. Accessed: out. 02, 2012. doi: 10.1590/S0100-06832011000300017.

CHAVEZ, L.F. et al. Carbon dioxide efflux in a Rhodic Hapludox as affected by tillage systems in Southern Brazil. Revista Brasileira de Ciência do Solo, v.33, p.325-334, 2009. Available from: <http://www.scielo.br/scielo.php?script= sci_arttext\&pid=S0100-06832009000200010\& lng=en\&nrm=iso\&tlng=en>. Accessed: out. 02, 2012. doi: 10.1590/S0100-06832009000200010.
ESCOBAR, L.F et al. Postharvest Nitrous Oxide Emissions from a Subtropical Oxisol as influenced by Summer Crop Residues and Their Management. Revista Brasileira de Ciência do Solo, v.34, p.507-516, 2010. Available from: <http:// www.scielo.br/scielo.php?pid=S0100-06832010000200024 \&script=sci_arttext $>$. Accessed: out. 02, 2012. doi: 10.1590/ S0100-06832010000200024.

GOMES, J. et al. Soil nitrous oxide emissions in long-term cover crops-based rotations under subtropical climate. Soil and Tillage Research, v.101, p.36-44, 2009. Available from: <http://www.sciencedirect.com/science/article/pii/ S0167198709001780>. Accessed: out. 02, 2012. doi: 10.1016/ j.still.2009.10.001.

LOVANH, N. et al. Determination of ammonia and greenhouse gas emissions from land application of swine slurry: A comparison of three application methods. Bioresource Technology, v.101; p.1662-1667, 2010. Available from: <http:/ /www.sciencedirect.com/science/article/pii/S09608524 09013297>. Accessed: out. 02, 2012. doi: 10.1016/ j.biortech.2009.09.078.

Ciência Rural, v.43, n.2, fev, 2013. 
LUMASENSE Technologies. INNOVA 1412 user's manual. Ballerup, DN: Lumansense Technologies. 2009. 280p.

PES, L.Z. et al. The primary sources of carbon loss during the crop-establishment period in a subtropical Oxisol under contrasting tillage systems. Soil and Tillage Research, v.117, p.163-171, 2011. Available from: <http://www.sciencedirect.com/ science/article/pii/S0167198711001681>. Accessed: out. 02, 2012. doi: 10.1016/j.still.2011.10.002.

RICE, C.W. Introduction to special section on greenhouse gases and carbon sequestration in agriculture and forestry. Journal of Environmental Quality, v.35, p.1338-1340, 2006. Available from: <https://www.soils.org/publications/jeq/articles/ 35/4/1338>. Accessed: out. 02, 2012. doi: 10.2134/ jeq2006.0001.

SAS Institute. SAS/STAT ${ }^{\circledR}$ 9.2: User's Guide. Cary, NC: SAS Institute Inc., 2009. 8444p.

SHERLOCK, R.R. et al. Ammonia, methane, and nitrous oxide emission from pig slurry applied to a pasture in New Zealand. Journal of Environmental Quality, v.31, p.1491-501, 2002. Available from: <https://www.soils.org/publications/jeq/articles/ 31/5/1491>. Accessed: out. 02, 2012. doi: 10.2134/ jeq2002.1491.

VELTHOF, G.L. et al. Nitrous oxide emission from animal manures applied to soil under controlled conditions. Biology and Fertility of Soils, v.37, p.221-230, 2003. Available from: <http://www.springerlink.com/content/19gx2jtlrq2fp3y9>. Accessed: out. 02, 2012. doi: 10.1007/s00374-003-0589-2.
VIEIRA, F.C.B. et al. Building up organic matter in a subtropical paleudult under legume cover-crop-based rotations. Soil Science Society of America Journal, v.73, p.1699-1706, 2009. Available from: <https://www.soils.org/publications/sssaj/ articles/73/5/1699>. Accessed: out. 02, 2012. doi: 10.2136/ sssaj2008.0241.

YAMULKI, S.; JARVIS, S.C. Automated chamber technique for gaseous flux measurements: Evaluation of a photoacoustic infrared spectrometer-trace gas analyzer. Journal of Geophysical Research, v.104, p.5463-5469, 1999. Available from: <http:// www.agu.org/journals/jd/v104/iD05/1998JD100082>. Accessed: out. 02, 2012. doi: 10.1029/1998JD100082.

ZANATTA, J.A. et al. Soil organic carbon accumulation and carbon costs related to tillage, cropping systems and nitrogen fertilization in a subtropical Acrisol. Soil and Tillage Research, v.94, p.510519, 2007. Available from: <http://www.sciencedirect.com/science/ article/pii/S0167198706002418>. Accessed: out. 02, 2012. doi: 10.1016/j.still.2006.10.003.

ZANATTA, J.A. et al. Nitrous oxide and methane fluxes in South Brazilian Gleysol as affected by nitrogen fertilizers. Revista Brasileira de Ciência do Solo, v.34, p.1653-1665, 2010. Available from: <http://www.scielo.br/scielo.php?pid=S010006832010000500018 \&script=sci_arttext $>$. Accessed: out. 02, 2012. doi: 10.1590/S0100-06832010000500018.

ZSCHORNACK, T. et. al. Mitigation of methane and nitrous oxide emissions from flood-irrigated rice by no incorporation of winter crop residues into the soil. Revista Brasileira de Ciência do Solo, v.35, p.623-634, 2011. Available from: <http://www.scielo.br/ scielo.php?pid=S0100-06832011000200031\&script=sci_arttext $>$. Accessed: out. 02, 2012. doi: 10.1590/S0100-06832011000200031. 